\title{
Drop in Overinvestment, Marginal value of Cash Holdings, and Governance System of Companies Listed on Tehran Stock Exchange
}

\author{
Adel Vahedi ${ }^{1 *}$, Hamidreza Mohammadi ${ }^{1}$
}

\begin{abstract}
This study aimed to investigate overinvestment, marginal value of cash holdings, and governance system of companies listed on Tehran Stock Exchange (TSE). For this purpose, 159 companies listed on TSE during five years (2011-2015) in 795 observations were studied and hypotheses were tested using panel data method in EViews. The results showed that there is an inverse and significant relationship between market value of cash holdings level and overinvestment of the company but governance system did not influence the inverse and significant relationship between market value of cash holdings level and overinvestment.
\end{abstract}

Keywords: overinvestment, cash holdings level, governance system

\section{Introduction}

Business units are faced by numerous investment opportunities and require reasonable decisions for investment efficiency. Indeed, investment of each business unit should be based on the limitation of resources and their efficiency. However, the main issue is to select plans and making decisions about investment opportunities by managers of business units that are according to their personal interests [23]. In other words, information asymmetry and conflict of interest prevent a desirable investment [26]. Therefore, business units, for investment in new plans, should consider the limits of investment according to the limitations of resources [17].

\section{Statement of the Problem}

Previous studies pointed to a direct relationship between investment costs and cash flow [6,8]. Similarly, Richardson [22] concluded that overinvestment occurs in companies with high levels of cash flow that indicates increased representation costs in companies with additional cash flows followed by useless expenses by the manager [11, 25]. Additional cash increases limited resources that are under control. Therefore, this probability increases that these resources will be spent in projects that lack specific results and destruct the value of shareholders [10]. Now, understanding the relationship between free cash flow and overinvestment, it should be taken into consideration that what value is considered by the market for cash flow and how this valuing changes with respect to investment decisions of the company.

According to Jensen and Mckling [10] and Myers and Rajan [19], holdings level of cash flow may provide cash for managers in order to maintain investment in projects with low

\footnotetext{
$\mid{ }^{1}$ Department of Accounting, Faculty of Literature and Humanities, Zahedan Branch, Islamic Azad University, Zahedan, Iran.

|*Corresponding Author
} 
returns to obtain personal interests instead of increasing the value of shareholders. Hanson [7] and Smith and Kim [24] concluded that additional free cash flow leads to decreased stock returns. These results can be interpreted in this way that high levels of additional free cash flows destruct the value of the company. These results show that there is a relationship between investment activities of a company and holdings level of cash. Another issue in the present study is the effect that governance system of the company can have on inverse effect of overinvestment in market value of cash holding level. Numerous studies have indicated that companies with weak governance have higher levels of cash reserves compared with companies with suitable governance [3,4,12,15]. Moreover, Pinkowitz et al. [20] and Pinkowitz and Williamson [21] found out that cash holdings level is lower in countries in which protecting the rights of investors is weaker.

Similarly, Dittmar and Mahr-Smith [5] showed that the structure of governance system decreases representation problems relative to holding level and additional cash and increases the value of every additional dollar of cash holding level. Another group of studies confirmed the decreasing effect of business governance system on overinvestment and free cash flow. For example, Richardson [22] pointed out that companies with lower active shareholders will have more overinvestment and free cash flow. Therefore, corporate leadership can decrease representation problems related to overinvestment and free cash flow and it is expected that this can decrease the negative effect of overinvestment on market value of cash holding level.

\section{Review of Literature}

The most important studies on this topic are as follow.

\subsection{Foreign studies}

Chen et al. [2] in their study entitled "free cash flow, overinvestment, and governance system in China" investigated this issue that how free cash flow and governance system characteristics influence investment level of the business. The results showed that overinvestment has a direct relationship with free cash flow while some mechanisms of governance system such as concentration of ownership and independence of board of directors can have an effective governance role.

Lee and Park [13] in their study entitled "can financial limitations of the board of directors have an important role in decreasing representational concerns about cash holding level?" found that leadership for companies with lower financial limitation leads to decreased concerns about holding level of cash. Also, lower financial limitation of companies increases leadership level of the board of directors and is more consistent with leadership standards of the board of directors. Their results indicate the dependence of financial limitation on leadership and cash holdings level.

Yuanto [27] in a study entitled "can leadership mechanisms of the business influence the value and holding level of cash?" investigated the relationship between corporate governance mechanisms and their effect on corporate vale in Singapore Stock Exchange. The results showed that companies with lower effectiveness are more interested in holding cash.

Lee [14] in a study entitled "cash holding, the structure of business governance system 
and corporate valuing" in five Asian countries (Malaysia, Philippines, India, Singapore, and Thailand) stated that if the board of directors plays corporate leadership role in these countries, it is predicted that companies with strong management structure have lower holdings level after controlling other factors. The results showed that companies with larger share of managers have lower cash holdings level in board of directors, separate situations of CEO, and chairman of the board.

\subsection{Internal studies}

Amiri et al. [1] evaluated the effect of business leadership mechanisms and financial limitations on cash holding level in companies listed on TSE. The results showed that the effect of financial knowledge, institutional investors, ownership concentration, and financial limitations on cash holdings level was significant in companies listed on TSE, but independence of the board of directors and its size did not influence cash holdings level in companies listed on TSE.

Moradi [18] investigated the effect of life span of company on the relationship between corporate leadership and cash holdings level. The results showed a significant relationship between all research variables with cash holding level. The results of Wong test showed that the effects of business leadership variables on cash holdings level are equal in growth and decline levels and the effectiveness level in these two levels is smaller compared with maturity level.

Mahmoodabadi and Mehtari [16] investigated the relationship between investment efficiency and accounting in companies listed on TSE. The results of their study showed that there is a significant relationship between accounting conservatism and future investment in companies and seven groups of industries. Also, a negative relationship was observed between the size of company and future investments in chemical, food, and medicine industries and significant positive relationship was observed between market value to book value and future investments in companies and wood, chemical, metal, and ceramics industries. Moreover, a significant negative relationship was observed between financial leverage and future investments in companies, and food and medicine industries.

Saghafi et al. [23] studied the quality of accounting information, overinvestment, and free cash flow. The results showed that with higher quality of accounting information, overinvestment rarely occurs and this relationship is almost seen in companies with higher free cash flows and the effect on overinvestment through the quality of accounting information is higher in these companies.

Izadinia and Rasaeian [9] investigated the relationship between corporate governance instruments, cash holding level, and performance of companies listed on TSE. The results of their study indicated that there is a significant positive relationship between the percentage of institutional investors ownership and the value of companies listed on TSE, but no significant relationship was observed between board of directors and the value of companies listed on TSE. Cash holdings level and the value of companies listed on TSE showed a significant positive relationship.

\section{Population of the Study}

Population of the study constitutes the foundation of the study. Population is 
consisted on people of units at least with one common attribute. The population in this study includes companies listed on TSE between 2011 and 2015. Following conditions and limitations were considered to select sample with random sampling method and systematic sample removal.

1. Companies with no change in financial period during the study.

2. They should not be among the companies that are active on financial activities such as investment companies, banks, insurance, and financial institutes. Since these institutes are different in terms of activities and their main incomes are resulted from investment, therefore, they are basically different from other companies and will be excluded from sample.

3. Available data for research variables should be available between 2011 and 2015 .

4. Their financial periods should end in March 20 to use data in panel mode.

\section{Research Hypotheses}

This study investigates how overinvestment influences market value of cash holdings level. Also, this question is taken into consideration that does governance system influence the relationship between overinvestment and cash holdings level. According to Myers and Rajan [19], available properties can become private properties with lower costs. Therefore, available properties provide an opportunity to investigated reasons related to representation theory. According to this reasoning, this point is taken into consideration that managers are interested in more investments with high cash reserves. If cash helps the company to take projects that destroy value, it is expected that companies which hold a large amount of cash, experience overinvestment and have lower value compared with companies that rarely pay attention to overinvestment. In the marginal relationship between market value and cash holding level, the following conditions are hypothesized:

H1: there is an inverse and significant relationship between market value of cash holdings level and overinvestment level.

Previous studies have pointed out that governance system has a fundamental effect on cash value in conditions in which efficient strategic system structures lead to decreased problems regarding cash holdings. We expect that governance system mechanisms play an inverse and negative role between overinvestment and marginal value of cash holdings. Therefore, we have the following hypothesis:

H2: Corporate governance system mechanisms influence the inverse relationship of overinvestment and market value of cash holdings level.

Evidences that confirm these hypotheses support this perspective that with the emergence of overinvestment, additional costs related to representation occur for shareholders while cash holding value is related to leadership mechanisms that decreased the inverse effect of overinvestment on market value of cash holdings level.

\section{Explaining and Measuring Research Variables}

Research variables are divided into three classes of dependent, independent, and control variables that will be explained. 


\subsection{Dependent Variable}

Dependent variable is the variable that is measures or observed to specify the effect of independent variable on it. In other words, dependent variable is under the influence of independent variable. According to the above definition and previous studies, dependent variable of this study is market value of cash holding level.

To assess market value of cash holding level, the following model is used:

$V_{i, t}=\beta_{0}+\beta_{1} E_{i, t}+\beta_{2} d_{i, t}+\beta_{3} R_{i, t}+B_{4} d R D_{i, t}+\beta_{5} I_{i, t}+\beta_{6} d_{i, t}+\beta_{7} D_{i, t}+\beta_{8} d_{i, t, t}+$ $\mathrm{B}_{9} \mathrm{dL}_{\mathrm{i}, \mathrm{t}}+\varepsilon_{\mathrm{i}, \mathrm{t}}$

Where Vi,t is market value of company $i$ at year $t$ that equals natural logarithm resulted from the sum of market value of shareholders and book value of debts.

$\mathrm{dLi}$,t: changes in cash holding level in company $\mathrm{i}$ at year $\mathrm{t}$ that equals cash holding level at year $\mathrm{t}$ minus cash holdings level of company at $\mathrm{t}-1$.

Ei,t: profitability of the company. To measure profitability, net profit to total assets has been used.

dEi,t: profitability changes if company $i$ at year $t$ that equals net profit ratio to company's assets at year $\mathrm{t}$ minus net profit ratio to company's assets at year $\mathrm{t}-1$.

$\mathrm{RDi}$,t: voluntary expenses of company $i$ at year 2 that equal the ratio of general, office, and sales expenses to assets.

dRDi,t: the changes in company i's voluntary expenses at year $t$ that equal the ratio of general, office, and sales expenses to company's assets at year t minus general, office, and sales expenses to company's assets at year t- 1 .

Di,t: direct profit of company $i$ at year $t$ that equals direct profitability to assets.

$\mathrm{dDi}, \mathrm{t}$ : profitability changes in company $\mathrm{i}$ at year $\mathrm{t}$ that equal the ratio of profitability to company's assets at year t minus the ratio of profitability to company's assets at year t-1.

\subsection{Independent Variables}

Independent variables of the present study are overinvestment and governance system factors that their effects on dependent variable will be investigated.

Overinvestment of company $i$ at year $t$ will be estimated by the following relationship proposed by Chen et al. [2].

$I_{N E W, t}=I_{\text {TOTAL }, t}-I_{\text {MANTENANCE, }}$

$I_{N E W, t}=I_{N E W, t}^{*}+I_{N E W, t}^{\varepsilon}$

$C F_{A I P, t}=C F O-I_{\text {MAINTENANCE, }}$

$F C F_{t}=C F_{A I P, t}-I_{N E W, t}^{*}$

Where:

INEW,t: new investments in projects.

ITOTAL,t: total investments that equal the sum of net investment activities.

IMAINTENANCE: essential investment expenses to hold assets that equal depreciation cost.

I*NEW: new expected investments.

Is NEW: unexpected new investments.

CFAIP,t: cash flow resulted from available assets that equals difference in $\mathrm{CFO}$ and essential investment expenses to hold assets (IMAINTENANCE).

FCFt: free cash flow that is obtained from available assets and new expected 
investments.

Therefore, estimation of free cash flow requires estimation of new expected investments and the following relationship is used to estimate it that is proposed by Chen et al. [2]:

$\mathrm{I}_{\mathrm{NEW}, \mathrm{t}}=\beta_{0}+\beta_{1}$ Growth $_{\mathrm{t}-1}+\beta_{2}$ Leverage $_{\mathrm{t}-1}+\beta_{3}$ Cash $_{\mathrm{t}-1}+\beta_{4}$ Age $_{\mathrm{t}-1}+$

$\beta_{5}$ Size $_{\mathrm{t}-1}+\beta_{6}$ Stockreturn $_{\mathrm{t}-1}+\beta_{7} \mathrm{I}_{\mathrm{NEW}, \mathrm{t}-1}+\varepsilon_{\mathrm{t}}$

where:

INEW,t: new investments on projects that equal the difference of company's investments and essential investment expenses to hold assets.

GROWTH: growth opportunities of the company that equal the ratio of market value of shareholders' right to book value.

Leverage: the ratio of debts to assets.

Cash: the ration of cash to assets.

Age: the age of company is measured based on year.

Size: the size of company that equals the logarithm of assets.

Stockreturn: refers to the sum of cost difference of each share at the end and beginning of the year and cash profit of each share on the cost of each share.

After estimating the above model at the level of data and estimating the coefficients of variables, estimation coefficients are used for each company-year and the wastes for each company-year $(\varepsilon)$ indicate new unexpected investments $\left(\mathrm{I}_{\mathrm{NEW}, \mathrm{t}}\right)$ and total difference of new investments and new unexpected investments will be equal. Therefore, according to Chen et al. [2], during this process, it is likely to estimate new unexpected investments $\left(\mathrm{I}^{{ }} \mathrm{NEW}, \mathrm{t}\right)$ where the positive values indicate overinvestment and this variables gets 1 and its negative values indicate insufficient investment and this variable gets zero in this condition.

GovFactorsi,t: governance factors of company i at year $\mathrm{t}$ include the following criteria:

1. Major ownership: percentage share under the ownership of major shareholders (owners who have more than $5 \%$ share).

2. Independence of the board of directors: the ratio of non-executive members of the board to total members.

3. The quality of independent auditing quality: if the auditing institute of the company is the auditing organization, it gets 1 ; otherwise, it gets zero.

\subsection{Control Variables}

DDummyi,t: cash profit payment by company i at year $t$.

$\mathrm{CFi}$,t: operating cash flow of company $i$ at year $t$.

NWCi,t: net capital in circulation of company $i$ at year $t$.

$\mathrm{CFi}$,t: operating cash flow of company $i$ at year $t$.

Levi,t: the ratio of debts to the assets of company $i$ at year $t$.

RDi,t: voluntary expenses of company $i$ at year $t$.

\section{Research Patterns}

Multivariate regression patterns of hypotheses testing are as follow:

\section{The model related to $\mathrm{H} 1$ :}

(1) $\mathrm{MVCH}_{\mathrm{i}, \mathrm{t}}=\beta_{0}+\beta_{1} \mathrm{DDummy}_{\mathrm{i}, \mathrm{t}}+\beta_{2} \mathrm{CF}_{\mathrm{i}, \mathrm{t}}+\beta_{3} \mathrm{NWC}_{\mathrm{i}, \mathrm{t}}+\beta_{4} \mathrm{CE}_{\mathrm{i}, \mathrm{t}}+\beta_{5} \operatorname{Lev}_{\mathrm{i}, \mathrm{t}}+\beta_{6} \mathrm{RD}_{\mathrm{i}, \mathrm{t}}+\beta_{7}$ $\mathrm{I}_{\mathrm{NEW}, \mathrm{t}}+\varepsilon_{\mathrm{i}, \mathrm{t}}$ 
The model related to $\mathrm{H} 2$ :

(2) $\mathrm{MVCH}_{\mathrm{i}, \mathrm{t}}=\beta_{0}+\beta_{1} \mathrm{I}_{\mathrm{NEW}, \mathrm{t}}+\beta_{2} \mathrm{CF}_{\mathrm{i}, \mathrm{t}}+\beta_{3} \mathrm{NWC}_{\mathrm{i}, \mathrm{t}}+\beta_{4} \mathrm{CE}_{\mathrm{i}, \mathrm{t}}+\beta_{5} \operatorname{Lev}_{\mathrm{i}, \mathrm{t}}+\beta_{6} \mathrm{RD}_{\mathrm{i}, \mathrm{t}}+$ $\mathrm{B}_{7}$ DDummy $_{\mathrm{i}, \mathrm{t}}+\beta_{8}$ GovFactors $_{\mathrm{i}, \mathrm{t}}+\varepsilon_{\mathrm{i}, \mathrm{t}}$

\section{Research Findings}

In this study, to classify data and perform calculations on data, Excel was used. Also, to perform required regressions, EViews was used. Moreover, the confidence level to test hypotheses is $95 \%$. Furthermore, in order to test hypotheses, panel data method was used. In panel data method, in order to select among panel data and mixed data, F-Limer test was used and according to this test, panel data was used to test $\mathrm{H} 1$ and $\mathrm{H} 2$. Also, according to the use of panel data in hypotheses, according to Hausman statistics, the use of fixed effects method was determined. To estimate regression models parameters, classic hypotheses testing is very important. Hypotheses that are related to the normality of model, lack of autocorrelation, lack of linearity, and lack of variance between models ae the most important hypotheses. To test the normality of the remaining, Jarque-Bera test was used. The results of this test show that the rest of models do not have normal distribution. In order to investigate autocorrelation between remaining values, Durbin-Watson test was used. The amount of this statistic for the first and second models show autocorrelation between the remaining values. In this regard, Breusch-Godfrey test was used to remove first-order autocorrelation between data. About investigating the linearity, it should be noted that mixed data method prevents auto-linearity. In order to investigate the existence of disparity variance between the remaining, Waldrich test was used. The results of this test showed that inconsistency exists in models of interest and it has been attempted to solve it. Table (1) shows descriptive statistics related to research variables that indicate descriptive parameters for each variable.

Table 1. Descriptive statistics of research variables

\begin{tabular}{lccccccc}
\hline Variables & $\begin{array}{c}\text { Number of } \\
\text { observations }\end{array}$ & Mean & Median & $\begin{array}{c}\text { Domain of } \\
\text { changes }\end{array}$ & SD & $\begin{array}{c}\text { Skewness } \\
\text { coefficient }\end{array}$ & $\begin{array}{c}\text { Kurtosis } \\
\text { coefficient }\end{array}$ \\
\hline MVCH & 795 & 13.977 & 13.780 & 8.940 & 1.492 & 0.704 & 3.823 \\
\hline I\&NEW & 795 & 0.000 & -1526.23 & 12870979.00 & 533247.90 & 0.460 & 74.255 \\
\hline Gov1 & 795 & 0.784 & 0.820 & 1.000 & 0.178 & -1.390 & 5.758 \\
\hline Gov $_{2}$ & 795 & 0.642 & 0.600 & 1.000 & 0.224 & -0.824 & 3.716 \\
\hline Gov 3 & 795 & 0.009 & 0.010 & 0.010 & 0.003 & -3.284 & 11.786 \\
\hline CF & 795 & 0.124 & 0.110 & 1.170 & 0.133 & 0.628 & 4.819 \\
\hline NWC & 795 & 0.081 & 0.100 & 2.220 & 0.255 & -1.274 & 7.934 \\
\hline CE & 795 & 0.033 & 0.010 & 2.670 & 0.126 & -3.496 & 79.652 \\
\hline Leverage & 795 & 0.650 & 0.620 & 2.620 & 0.284 & 2.205 & 12.538 \\
\hline RD & 795 & 0.060 & 0.050 & 0.480 & 0.047 & 2.453 & 13.794 \\
\hline DDummy & 795 & 0.010 & 0.010 & 0.010 & 0.0004 & -28.143 & 793.001 \\
\hline
\end{tabular}

Table 2. The results of estimating the first research model

Dependent variable, market value of cash holdings level

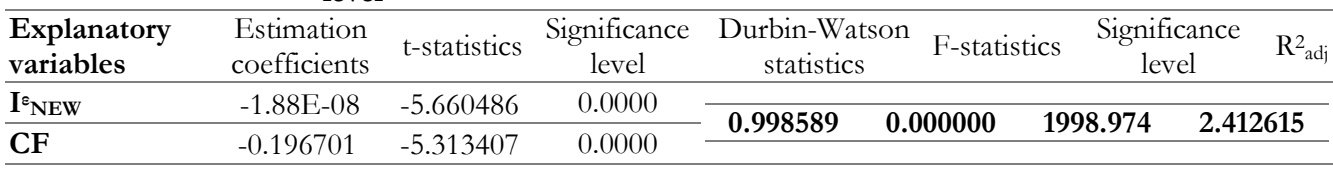




\begin{tabular}{lccc}
\hline NWC & -0.088130 & -2.202594 & 0.0281 \\
\hline CE & 0.380971 & 9.475405 & 0.0000 \\
\hline LEVERAGE & -0.272269 & -4.720007 & 0.0000 \\
\hline RD & -2.585688 & -10.57517 & 0.0000 \\
\hline DDUMMY & 8.767235 & 0.919157 & 0.3585 \\
\hline C & 14.69622 & 138.7947 & 0.0000 \\
\hline AR(1) & 0.686990 & 46.18410 & 0.0000 \\
\hline
\end{tabular}

$\mathrm{H} 0$ points to the lack of significant relationship between dependent variable and independent variable and $\mathrm{H} 1$ points to a significant relationship between these variables. As can be seen in Table (2), new unexpected overinvestments as the independent variable and due to the significance level lower than $5 \%$ have a significant relationship with market value of cash holdings level at the confidence level if $95 \%$ and due to the negative value of Beta coefficient, this relationship is inverse. Therefore, H1 is confirmed and $\mathrm{HO}$ is rejected.

The results related to F-statistics (0.00000) show that model is significant and according to Durbin-Watson statistics $(2,41)$, it can be observed that the autocorrelation problem is solved and the model lacks serious autocorrelation. Moreover, the results related to coefficient of determination show that $0.9985 \%$ of changes in dependent variable are under the influence of independent and control variables of this study. The summary of regression estimation results related to $\mathrm{H} 2$ are presented in Table (3).

Table 3. The results of estimating the third model

Dependent variable: market value of cash holdings level

Method: fixed effects

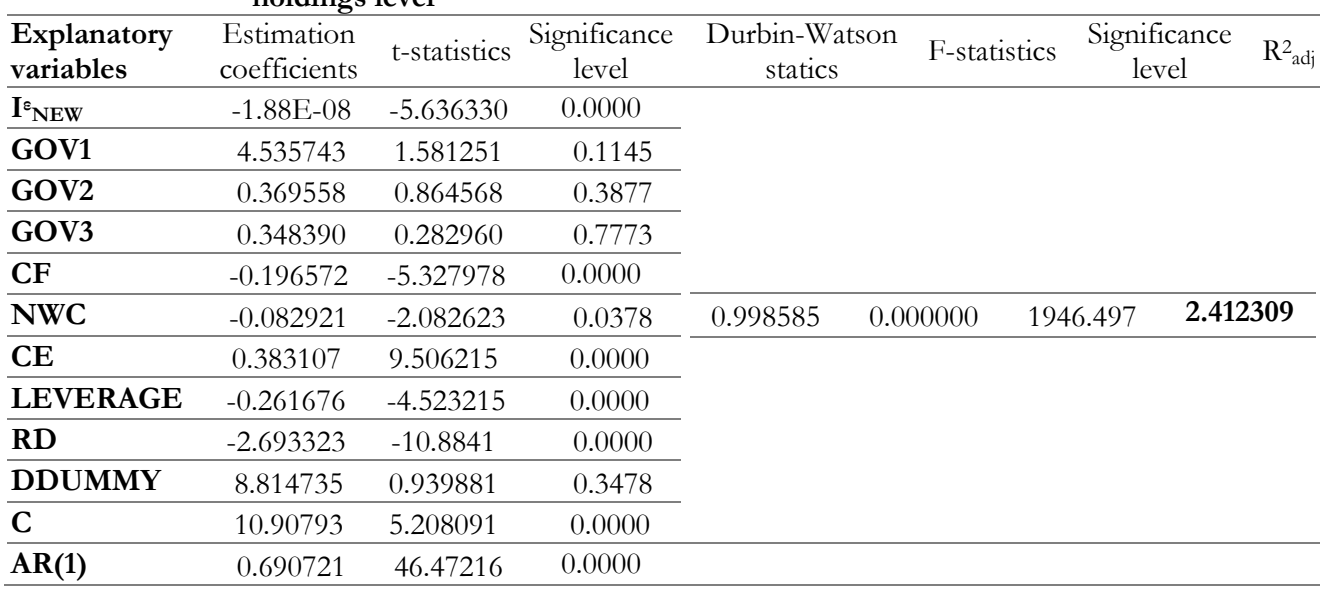

H0 points to the lack of significant relationship between dependent and independent variables and $\mathrm{H} 1$ points to a significant relationship between these variables. As can be seen in Table (3), new unexpected investments as independent variable and due to the significance level lower than $5 \%$ have a significant relationship with market value of cash holdings at the confidence level of $95 \%$, but governance system factors as independent variable and due to the significance level larger than $5 \%$ do not have a significant relationship with market value of cash holdings level at the confidence level of $95 \%$. As a result, $\mathrm{H} 0$ is confirmed and $\mathrm{H} 1$ is rejected. 
The results related to F-statistics (0.00000) show that the model is generally significant and according to Durbin-Watson statistics $(2,41)$, it was specified that the autocorrelation problem is solved and the model does not have any serious autocorrelation. Moreover, the results related to the adjusted coefficient of determination show that $0.9985 \%$ of changes in dependent variable have been under the influence of independent and control variables of this study.

\section{Conclusion}

The results of statistical methods for $\mathrm{H} 1$ showed a significant and inverse relationship between market value of cash holdings level and overinvestment and this relationship shows that with higher overinvestment, market value of cash holdings level decreases. The results of $\mathrm{H} 2$ showed that governance system factor does not have any effect on inverse relationship of cash holdings market value and overinvestment.

\section{Limitations of the Study}

There are always some limitations that prevent the normal procedure and influence the results. It is obvious that the effect of these factors in some cases leads to the negligence of results and in other cases intensifies them. In both conditions, controlling the effects of these factors is very important. The major limitations of the present study that may influence generalizability of the results are as follow:

1. Limitation related to data collection. In similar studies in other countries, more companies were selected (e.g. 1000 samples). Second, they include longer intervals and their data were as datasets and this leads to spending shorter time to collect data and analyze them.

2. Existence of certain conditions such as unpredicted events and political conditions that influence companies and counties that have not been considered in this study. Therefore, necessary care should be considered in generalizing the results.

3. In this study, the extracted data from financial statements were not adjusted with inflation. Therefore, according to difference inflation rate in these years, if the used data were adjusted, different results could be obtained.

\section{Suggestions for Future Studies}

In order to conduct studies in this regard, the following topics are suggested:

1. The use of other governance system variables such as political relationships of the board, quality of financial information, the size of the board, independent audit.

2. Comparative investigation of research topic in distinct samples based on the type of industry.

3. Comparative investigation of research topic in distinct samples based on the size companies listed on TSE.

4. Conducting the present study using other control variables.

\section{References}

Amiri, S., Amiri, A., Sedigh, S. (2014). Investigating the effect of business system mechanisms and financial limitations on cash holdings level in companies listed in TSE, the first conference on accounting, Jami Institute of Higher Education. 
Chen, X., Sun, Y. and Xu, X. (2015). Free Cash Flow, Over-Investment and Corporate Governance in China. Pacific-Basin Finance Journal, doi: 10.1016/j.pacfin. 2015.06.003.

Claessens, S., Djankov, S., Fan, J.P. and Lang, L.H. (2002). Disentangling the incentives and entrenchment effects of large shareholdings. Journal of Finance, 57 (6), 2741-2771.

Dittmar, A., J. Mahrt-Smith, and H. Servaes, (2003). International Corporate Governance and Corporate Cash Holding, Journal of Financial and Quantitative Analysis, 38, 111-133.

Dittmar, A. and Mahrt-Smith, J. (2007). Corporate governance and the value of cash holdings. Journal of Financial Economics, 83 (3), 599-634.

Fazzari, S., Hubhard, M. R. and Petersen, B. (1988). Financing constraints and corporate investment. Brooking Papers on Economic Activity, 1(1), 141-195.

Hanson, R. C. (1992). Tender offers and free cash flow: An empirical analysis. The Financial Review, 27 (2), 185-209.

Hubbard, R. G. (1998). Capital market imperfections and investment. Journal of Economic Literature, 36 (1), 193-225.

Izadinia, N., Rasaeian, A. (2010). Instruments in corporate governance, cash holdings level, and performance of companies listed on TSE, Journal of Economic Studies, 55, 141-154.

Jensen, M. C. and Meckling, W. H. (1976). Theory of the firm: Managerial behavior, agency costs and ownership structure. Journal of Finance Economics, 3 (4), 305-360.

Jensen, M. (1986). "Agency cost of free cash flow, corporate finance, and takeovers". Am. Economics Review. 76(2),3-43.

La Porta, R., Lopez-de-Silanes, F., Shleifer, A. and Vishny, R. (2002). Investor protection and corporate valuation. Journal of Finance, 57 (3), 1147-1170.

Lee, C. and Park, H. (2015). Financial Constraints, Board Governance Standards, and Corporate Cash Holdings. Review of Financial Economics, doi: 10.1016/j.rfe. 2015.10.001.

Lee, C.F. (2009). Cash Holdings, Corporate Governance Structure and Firm Valuation. Review of Pacific Basin Financial Markets and Policies, 12(3), 475-508.

Lins, K. V. (2003). Equity ownership and firm value in emerging markets. Journal of Financial and Quantitative Analysis, 38(1), 159-184.

Mahmoodabadi, H., Mehtari, Z. (2011). The relationship between accounting conservatism and investment efficiency of companies listed on TSE. Journal of Accounting Progresses, University of Shiraz, 113-140.

Modarres, A., Hesarzadeh, R. (2008). The quality of financial reporting and investment efficiency. Journal of Stock Exchange, 85-116.

Moradi, J. (2013). Investigating the effect of company's life cycle on the relationship between corporate governance and cash holdings level, MA thesis, Islamic Azad University of Marvdasht.

Myers, S. C., Rajan, R. G., 1998. The paradox of liquidity. Quarterly Journal of Economics 113(3), 733-771.

Pinkowitz, L., Stulz, R. and Williamson, R. (2006). Does the contribution of corporate cash holdings and dividends to firm value depend on governance? A cross-country analysis. Journal of Finance, 61 (6), 2725-2751.

Pinkowitz, L. and Williamson, R. (2007). What is the market value of a dollar of corporate Cash? Journal of Applied Corporate Finance, 19 (3), 74-81.

Richardson, S. (2006). Over-investment of free cash flow. Review of Accounting Studies, 11: 159-189.

Saghafi, A., Bolo, Gh., Mohammadian, M. (2011). The quality of accounting information, overinvestment, and free cash flow, Journal of Accounting Progresses, University of Shiraz, 37-63.

Smith, R. L. and Kim, J. H. (1994). The combined effects of free cash flow and financial slack on bidder and target stock returns. Journal of Business, 67 (2), 281-310.

Stulz, R. M. (1990). Managerial discretion and optimal financing policies. Journal of Financial Economics, 26 (1), 3-27.

Yang, J., and Jiang, Y. (2008). Accounting information quality, free cash flow and overinvestment: A Chinese study. The Business Review, 11 (1): 159-166.

Yuanto, K. (2011). Do corporate governance mechanisms matter for cash holdings and firm value?. Journal Of Corporate Finance, 17, 725-740. 